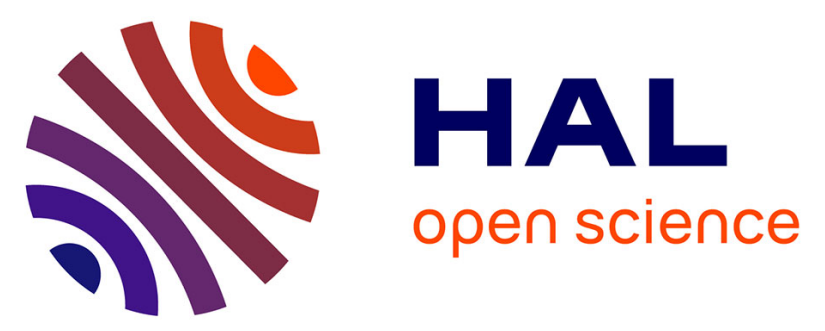

\title{
Promoting Innovation by Adding Entrepreneurial Education to a Natural Sciences Curriculum-Case Tanzania
}

\author{
Ville Taajamaa, Emma Nkonoki, Antero Järvi, Lauri Hooli
}

\section{To cite this version:}

Ville Taajamaa, Emma Nkonoki, Antero Järvi, Lauri Hooli. Promoting Innovation by Adding Entrepreneurial Education to a Natural Sciences Curriculum-Case Tanzania. 1st International Conference on Sustainable ICT, Education, and Learning (SUZA), Apr 2019, Zanzibar, Tanzania. pp.1-6, 10.1007/978-3-030-28764-1_1 . hal-02515731

\section{HAL Id: hal-02515731 \\ https://hal.inria.fr/hal-02515731}

Submitted on 23 Mar 2020

HAL is a multi-disciplinary open access archive for the deposit and dissemination of scientific research documents, whether they are published or not. The documents may come from teaching and research institutions in France or abroad, or from public or private research centers.
L'archive ouverte pluridisciplinaire HAL, est destinée au dépôt et à la diffusion de documents scientifiques de niveau recherche, publiés ou non, émanant des établissements d'enseignement et de recherche français ou étrangers, des laboratoires publics ou privés. 


\title{
Promoting Innovation by Adding Entrepreneurial Education to a Natural Sciences Curriculum-Case Tanzania
}

\author{
Ville Taajamaa, Emma Nkonoki, Antero Järvi, Lauri Hooli, \\ University of Turku, FIN-20014, Finland \\ emma.nkonoki@utu.fi
}

\begin{abstract}
This paper presents the results from train-the-trainer workshop held for Tanzanian university faculty from four different universities. The aim of the workshop was to build entrepreneurial education capacity and competencies of local faculty. Findings from the workshop were planned to be integrated into the existing curricula of the universities together with activating and studentcentred teaching methods. Main approaches were Problem based Learning and Design thinking.

This was the first workshop in a multi-year project with main intention and focus set on innovative and entrepreneurial education from the perspective of knowledge, skills and mindset.

The results show that participants of the workshop understood both at a general and at a context level how to add entrepreneurial practices and mindset to the natural sciences based curriculum. This was also the main aim of the workshop. Concerning educational content challenges there was more distribution among answers. Participants had different challenges concerning the topic. Process wise the practical and activating approach to the training was well understood and received. One of the main challenges was the question how to implement new approaches to the existing curricula
\end{abstract}

Keywords: Innovation, Entrepreneurial Education, Design Thinking, Problem Based Learning, University Curricula, East Africa

\section{Introduction}

This paper presents the results from train-the-trainer workshop held for East African faculty from four different universities from Tanzania. The aim of the workshop was to work on learn together how adding entrepreneurial competencies could be integrated into the existing curricula of the universities and what kind activating and student-centred teaching methods could be used.

The title of the workshop was; "Entrepreneurship, Innovation and Education". There were 12 participants, out of those 9 answered the survey, from junior faculty to professors with experience of department level management. All the participants were from natural sciences backgrounds mostly from either IT or Geography. Survey 
focused on knowledge base, quality of subject content, competencies and learnings from the workshop before and after. Workshop lasted for three full days and a half day. There were two coaches, both of whom are authors in this paper.

Looking through scientific silos or lingua academica underlying epistemological approach in training meant adding both pragmatic and social-constructivist worldviews to a typically positivistic, neo-, or post positivistic worldviews [1]. In practice it meant integrating activating teaching methods coupled with business approaches such as Problem based Learning, and Design thinking at the level of activities, processes, mind-set and methods [2]-[8]. Method wise the workshop consisted team based challenges and tasks that included ideation, need finding, and prototyping in a team and project based environment with open challenge settings. The program also included some business concept exercises and basics [2]-[8].

\section{Methodology}

For the most part the results were derived from the anonymous feedback survey that was disseminated after the workshop. It had both quantitative and qualitative parts. The quantitative data using Likert-scale was analysed using statistical tools and average was calculated [1]. The qualitative data was analysed thematically using thematic analysis and also ethnographic observation [1]. The analysis happened through first reading the open data several times, then finding different themes that emerged from the text and then coding the qualitative data based on those themes. The approach was close to thematic analysis method and had some elements from Grounded Theory Method as well [1].

\section{$3 \quad$ Results and Discussion}

The results show that the main aim of the workshop that is how to add entrepreneurial practices and mindset to the natural sciences based curriculum was well understood both at general and at context level. Concerning the challenges of the content there was distribution of the answers. Participants had different challenges concerning the topic. Process wise the practical and activating approach to the training was well understood and received. One of the main challenge found was the question how to implement new approaches to the existing curricula.

\subsection{Relevance to work and understanding}

As seen Table 1, in terms of workshop topic relevance to participants work the average was 4.7 out of 5.0. Participants were however somewhat confused about the content as the average for content coherence was only 3.9. This is a clear point that needs to be taken into consideration when planning for the iteration of the next workshop. 
Table 1. Relevance and coherence of the workshop topic. The participants understood well the importance of the topic and saw the linkage to their work. However, many of the participants felt that workshop content was something new to them. As discussed in the Discussion section one of the reasons can be that there was no pre-workshop material distributed to the participants who came from very different disciplines.

\begin{tabular}{|c|c|c|c|c|c|c|c|c|}
\hline & 1 & 2 & 3 & 4 & 5 & & Total & Average \\
\hline \multirow{2}{*}{$\begin{array}{l}\text { I see no linkage } \\
\text { with the topic to } \\
\text { my work/studies }\end{array}$} & 0 & 0 & 1 & 1 & 7 & \multirow{2}{*}{$\begin{array}{l}\text { The topic was } \\
\text { highly relevant to } \\
\text { my work/studies }\end{array}$} & \multirow[t]{2}{*}{9} & \multirow[t]{2}{*}{4.67} \\
\hline & $0 \%$ & $0 \%$ & $11.11 \%$ & $11.11 \%$ & $77.78 \%$ & & & \\
\hline \multirow{2}{*}{$\begin{array}{l}\text { Many topics } \\
\text { remained unclear }\end{array}$} & 0 & 0 & 1 & 4 & 4 & \multirow{2}{*}{$\begin{array}{l}\text { I understood } \\
\text { everything }\end{array}$} & 9 & \multirow[t]{2}{*}{4.33} \\
\hline & $0 \%$ & $0 \%$ & $11.11 \%$ & $44.45 \%$ & $44.44 \%$ & & & \\
\hline \multirow{2}{*}{$\begin{array}{l}\text { Workshop } \\
\text { contents felt } \\
\text { confusing }\end{array}$} & 0 & 1 & 2 & 2 & 3 & \multirow{2}{*}{$\begin{array}{l}\text { Workshop } \\
\text { contents were } \\
\text { coherent }\end{array}$} & 8 & \multirow[t]{2}{*}{3.88} \\
\hline & $0 \%$ & $12.5 \%$ & $25 \%$ & $25 \%$ & $37.5 \%$ & & & \\
\hline Total & 0 & 1 & 4 & 7 & 14 & & 26 & 4.31 \\
\hline
\end{tabular}

\subsection{Gaining of practical skills}

As seen Table 2, on an average 4.2 out of 5.0 felt that their theoretical knowledge about the topic had increased substantially and average 4.4 felt that their practical skills had increased substantially. Especially the increased practical skills can be seen as one of the main aims of the workshop. In Table 3 the respondents share their view on their theoretical and practical knowledge and skills in terms of the topic. As can be seen here the average 2.94, which is relatively low.

Table 2. Gaining of knowledge and practical skills. Clear majority of the participants thought that their theoretical knowledge as well as their practical skills related to the topic were increased substantially. This was also one of the aims of workshop.

\begin{tabular}{|c|c|c|c|c|c|c|c|c|}
\hline & 1 & 2 & 3 & 4 & 5 & & Total & Average \\
\hline I did not gain new & 0 & 0 & 1 & 5 & 3 & \multirow{2}{*}{$\begin{array}{l}\text { My theoretical } \\
\text { knowledge about } \\
\text { the topic has } \\
\text { increased } \\
\text { substantially }\end{array}$} & 9 & 4.22 \\
\hline $\begin{array}{l}\text { knowledge } \\
\text { about the topic }\end{array}$ & $0 \%$ & $0 \%$ & $11.11 \%$ & $55.56 \%$ & $33.33 \%$ & & & \\
\hline I did not learn & 0 & 0 & 0 & 5 & 4 & \multirow{2}{*}{$\begin{array}{l}\text { My practical skills } \\
\text { have increased } \\
\text { substantially }\end{array}$} & 9 & 4.44 \\
\hline $\begin{array}{l}\text { skills about the } \\
\text { topic }\end{array}$ & $0 \%$ & $0 \%$ & $0 \%$ & $55.56 \%$ & $44.44 \%$ & & & \\
\hline Total & 0 & 0 & 1 & 10 & 7 & & 18 & 4.33 \\
\hline
\end{tabular}


Table 3. Knowledge and practical background to the topic. In Table 1 it was shown that participants found some of the content confusing. As seen above in Table 3 this is supported by the fact that participants had little previous knowledge and practical skills of the topic.

\begin{tabular}{|c|c|c|c|c|c|c|c|c|}
\hline & 1 & 2 & 3 & 4 & 5 & & Total & Average \\
\hline \multirow{2}{*}{$\begin{array}{l}\text { No previous } \\
\text { theoretical } \\
\text { knowledge }\end{array}$} & 0 & 1 & 8 & 0 & 0 & \multirow{2}{*}{$\begin{array}{l}\text { Good theoretical } \\
\text { knowledge }\end{array}$} & 9 & 2.89 \\
\hline & $0 \%$ & $11.11 \%$ & $88.89 \%$ & $0 \%$ & $0 \%$ & & & \\
\hline \multirow{2}{*}{$\begin{array}{l}\text { No previous } \\
\text { practical skills }\end{array}$} & 0 & 1 & 7 & 1 & 0 & \multirow{2}{*}{$\begin{array}{l}\text { Good practical } \\
\text { skills }\end{array}$} & 9 & 3 \\
\hline & $0 \%$ & $11.11 \%$ & $77.78 \%$ & $11.11 \%$ & $0 \%$ & & & \\
\hline Total & 0 & 2 & 15 & 1 & 0 & & 18 & 2.94 \\
\hline
\end{tabular}

\subsection{Most important learning and what supported it}

In Table 4 the respondents described the most important things that they learned during the workshop. Five persons answered that understanding the link between theory and practice was the most important one. Also understanding the importance of business was emphasized to some extent. In Table 5 this is taken into workshop material level in terms of how the material supported the learning. Here the fact that the respondents felt that they did not receive enough theoretical background is understandably as the workshop focused on experiential and Problem based Learning and practical processes and methods. Coaching team decided that learning theoretical background is something that the participants can learn by themselves.

Table 4. Results from the question 'most important learnings during the workshop' supports the observations and discussions with the participants. As teachers and practitioners their concern is how to embed and integrate lessons learned into their daily practice. This is also one of the key challenges for future research especially from the perspective of grassroots innovation.

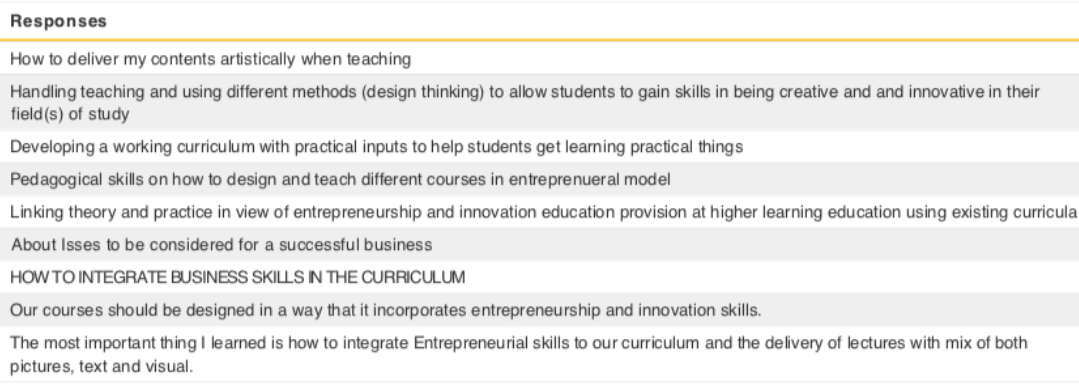


Table 5. How the workshop methods and material supported learning. According to results the participants would have needed more theoretical knowledge. The aim of the workshop was to focus on hands-on experiential experience about what it takes to use activating learning methods in the context of entrepreneurial education. From this perspective the result is logical. This topic was also discussed during and after the workshop and as a result a 'list of readings' was created and disseminated to the participants.

\begin{tabular}{|c|c|c|c|c|c|c|c|c|}
\hline & 1 & 2 & 3 & 4 & 5 & & Total & Average \\
\hline \multirow{2}{*}{$\begin{array}{c}\text { The } \\
\text { workshop } \\
\text { methods did } \\
\text { not support } \\
\text { my learning }\end{array}$} & 0 & 0 & 2 & 5 & 2 & \multirow{2}{*}{$\begin{array}{l}\text { The } \\
\text { workshop } \\
\text { methods } \\
\text { supported my } \\
\text { learning }\end{array}$} & 9 & 4 \\
\hline & $0 \%$ & $0 \%$ & $22.22 \%$ & $55.56 \%$ & $22.22 \%$ & & & \\
\hline \multirow{2}{*}{$\begin{array}{c}\text { The } \\
\text { workshop } \\
\text { materials did } \\
\text { not support } \\
\text { my learning }\end{array}$} & 0 & 0 & 0 & 4 & 4 & \multirow{2}{*}{$\begin{array}{l}\text { The } \\
\text { workshop } \\
\text { materials } \\
\text { supported my } \\
\text { learning }\end{array}$} & 8 & 4.5 \\
\hline & $0 \%$ & $0 \%$ & $0 \%$ & $50 \%$ & $50 \%$ & & & \\
\hline \multirow{2}{*}{$\begin{array}{l}\text { There was } \\
\text { not enough } \\
\text { theoretical } \\
\text { background } \\
\text { in the } \\
\text { workshop }\end{array}$} & 0 & 1 & 2 & 4 & 1 & \multirow{2}{*}{$\begin{array}{l}\text { The } \\
\text { theoretical } \\
\text { background } \\
\text { was } \\
\text { sufficiently } \\
\text { presented } \\
\text { during the } \\
\text { workshop }\end{array}$} & 8 & 3.63 \\
\hline & $0 \%$ & $12.5 \%$ & $25 \%$ & $50 \%$ & $12.5 \%$ & & & \\
\hline
\end{tabular}

\section{Conclusion}

It is important to understand that entrepreneurial education is not about giving answers or even paths and tools for solving them. It is about creating an environment for disruption where the learner is able to go through experiential cycles of learning and through that understanding the uniqueness of each context and situation. This creates a mind-set that enables innovation through testing. As the results show especially the set goals of the faculty learning practical skills and understanding the linkage between theory and practice were achieved. Although the duration of the workshop was four days it was still seen as too short. The future practical interventions and research will focus on furthering and deepening the approach of building-to-think, and going through experiential learning cycles in an actual open challenge setting utilizing different activating methods from lean management and design thinking. Given the setting of this study one of the future emphasis could be on grassroots innovations Grassroots innovations is one of the foundational contexts for East Africa and it has an important role to play in creating sustainable development and reduces inequality. Inequality is a very common challenge in developing countries and reducing it is actually one of the sustainable development goals 2030. One of the main hypothesis for one track of future studies is that that education and especially entrepreneurial education with the help of technology can function as a bridge builder between grassroots and systemic innovation. The general situation in East Africa now, sees a lot of top down approaches to innovations and less of the bottom up. The idea is that adding entrepreneurial education to the university's 
curricula will help students to empower themselves and empower others. Taking into account that everybody is creative and/or has the capacity to be creative, university graduates will be able to contribute into building an inclusive innovation ecosystem by emphasizing grassroots innovations.

\section{References}

1. Creswell,J.W.: "Research Design - Qualitative, Quantitative, and Mixed Methods Approach”. Third Edition. Sage Publications Inc., (2009)

2. Savin-Baden,M.: "Problem-Based Learning in Higher Education: Untold Stories". The Society for Research into Higher Education and Open University Press, Buckingham, UK, 126 and 124, (2000).

3. Graaff, E.,Kolmos,A.: “Characteristics of Problem-Based Learning”.Int. J. Engng Ed. Vol. 19 (5), 657-662 (2003)

4. Edström, K, Kolmos, A "PBL and CDIO: complementary models for engineering education development”.European Journal of Engineering Education. (2014)

5. Lehmann,M., Christensen,P., Du,X., Thrane,M.: "Problem-oriented and project-based learning (POPBL) as an innovative learning strategy for sustainable development in engineering education".European Journal of Engineering Education Vol.33 (3), 283-295 (2008)

6. Kimbell,L.:“Beyond design thinking: Design-as-practice and designs-inpractice”.CRESC,2009.

7. Kimbell,L.: "Rethinking Design Thinking: Part I, Design and Culture”. 3:3, 285-306(2011)

8. Kimbell,L.:;“ Rethinking Design Thinking: Part II, Design and Culture”, 4:2,129-148 (2012) 